\title{
Perception of public about early marriage based on education level
}

\author{
Ika Sandra Dewi ${ }^{1}$, Daharnis ${ }^{2}$, Syahniar ${ }^{3}$ \\ 123Universitas Negeri Padang, Padang - Indonesia, (dewisandra2692@yahoo.com)
}

\begin{abstract}
Public perception of early marriage has many variations. The education level is factors which influence it. Aims of this research are to description's differences public perception of early marriage based on education level. The method was ex-post facto with a threedesign. The population is the community of Sidojadi, Kecamatan Bukit Malintang, Kabupaten Mandailing Natal, consists of 888 people and samples were 276 people. The instrumentis a perception of public about early mirage by using Likert scale model andreliability test is 0.910 . Data were analyzed by using the descriptive statistics and ANOVA. The result of this research shows that there is a significant difference of public perception about early marriage based on the education level.
\end{abstract}

Keywords: perception of public, education level.

\section{Introduction}

Humans are social beings who need a partner to get on with life, one through marriage. Marriage is the birth and inner bond of a man with a woman as husband and wife with the aim of forming a happy family (household) based on the Supreme Godhead (Marriage Law of 1974). Individuals must maintain the continuity of marriage, in order to be a happy family and get offspring; maintaining the continuity of individual marriage must have a purpose to marry. The purpose of marriage is to meet basic human needs, relationship man and women in realizing a happy family with the basis of love and affection with following the provisions that have been set up by law (Sardi, 2016).

Married couples must have a mature and mature mindset to keep the household happy and defend until death separates. The ideal age of married women is 21-25 years and men 25-28 years (Dlori, 2005; Roqib, 2010; Sari, 2013), because at that age the female reproductive organs are physically well developed, strong and ready to give birth, as well as men at the age of $25-28$, will be ready to sustain the life of his family. however in fact, many men and women get married early. Married at a young age is called an early marriage.

Early marriage cases occur in many different backgrounds. The United Nations Children's Fund (UNICEF) found that early marriage is often found in Middle Eastern and South Asian societies and some sub-Saharan African communities (UNICEF, 2005). In South Asia, there are 9.7 million girls or $48 \%$ married under the age of 18, and in Africa by $42 \%$ (Pediatri, 2009). The Central Bureau of Statistics (BPS, 2016) found $34.2 \%$ of married women under the age of 20 years and men $11.9 \%$, while the ages of women giving birth between the ages of $13-18$ years reached $18 \%$ and marriages under the age of 18 reached $49 \%$. Social analysis indicates that early marriage is one of the obstacles to improve the quality of Human Resources (HR). Data from the Office of Religious Affairs (KUA) of Mandailing 
Natal District found that the number of adolescents who married early under 20 years in 2016 was $273(29.08 \%)$ of 945 married. Sidojadi is the highest village to conduct an early marriage in Bukit Malintang sub-district, Mandailing Natal Regency, which is 70 (25,70\%) from 276 married couples. The average population of Sidojadi has a junior high school level and works as a farmer.

Observations of researchers in the village Sidojadi Bukit Malintang District, Mandailing Natal District on September 2, 2016, some teenagers under the age of 20 many who married early. This happens because, among other things, teenagers experience failure in their education due to pregnancy out of wedlock and parents marry off children to cover up the family's disgrace. Many teenagers whose parents cannot afford to send their children to higher levels, so when there is a proposal to apply his daughter immediately accepted the application, although his son is still in secondary education. Most teenagers are married early in Sidojadi village after Idul Fitri and Idul Adha, as many nomads apply for young women to be taken abroad. The parents who get the proposal feel proud because he thinks his son's life will be changed and fulfilled. Though early marriage is vulnerable to divorce and Domestic Violence (KDRT). Not a few teenagers who get married early few months are divorced (Djamilah \& Kartikawati, 2016; Mustika, 2016).

Many views of society related to early marriage. Some people consider early marriage is a natural thing, but some people think early marriage can hamper the development of children to optimize their ability in achieving ideals so that perceptions appear to marriage early in society both positive and negative. Perception is a person's knowledge and belief in judging an object (Foedjiawati \& Semuel, 2009; Nagul, Yusuf \& Syahniar, 2013). Perception is the judgment that a person gives to a particular object or event (Azhar, Daharnis, \& Sukmawati, 2013). Based on these opinions can be concluded perception is a person's perspective on the object he sees.

Someone married early due to several factors. The factors driving early marriage are economic factors (Caldwell, 2005; Heckman, 2011; Stang, 2011; Astuty , 2013; Yunita, 2014; Fadlyana, Larasaty, \& Pediatri, 2016; Sardi, 2016), education (Fantuzzo, Tighe, \& Childs, 2000; Kurnianingtyas , 2009; Afifah, 2011; Qibtiyah , 2015; Fadlyana, Larasaty, \& Pediatri, 2016; Sardi, 2016; Dwinanda, Wijayanti, \& Werdani, 2017; Rahman, 2017), parents (Yunita, 2014; Sardi, 2016) and cultural (Billari, Philipov, \& Baizán, 2001; Aryanti, 2014; Sardi, 2016). The low economic capacity can be seen from the livelihoods of the local people who on average as agricultural laborers and women only become housewives. Parents who cannot afford to pay for life and school sometimes allow children to get married early (Sardi, 2016).

Education and knowledge have a relationship with early marriage. Teenagers who have mothers with low education are more prone to early marriage than teenagers who have mothers with higher education (Dwinanda, Wijayanti, \& Werdani, 2017). Research conducted by Vasanth, Ilayaraja \& Ramya (2015) found that there is no relationship between knowledge with the incidence of early marriage.

Based on the above opinion there is a difference of opinion about the factors that affect early marriage, namely the level of education. The existence of these differences of opinion invites researchers to conduct research on the public perception of early marriage in terms of education level. The purpose of this study to describe differences in public perceptions about early marriage $d$ from the level of education.

\section{Method}

This study used a quantitative approach of comparative descriptive type. The study population was 888 people and the sample was 276 people. Sampling using Proportional Random Sampling technique. The instrument of this research is Likert scale with reliability equal to 0,910 . To know the 
difference of public perception about early marriage in terms of education level analyzed using analysis of variance (ANOVA).

\section{Result and Discussion}

\section{Description of Public Perception Data on Early Marriage based on education level}

The difference of public perception about early marriage in terms of education level as a whole is obtained from respondents amounting to 276 people. Here is a description of the public perception data about early marriage as a whole.

Table 1. Description of Public Perception Data on Early Marriage based on education

level $(n=276)$

\begin{tabular}{|c|c|c|c|c|c|}
\hline \multicolumn{6}{|c|}{ Pablic Perception of Early A Iarmiage } \\
\hline Edreation I level & $\mathbf{N}$ & NTean & 96 & SIO & C \\
\hline \multirow{3}{*}{$\begin{array}{c}\text { Basic } \\
\text { Education }\end{array}$} & 27 & 164,67 & 64,57 & 20,50 & MI \\
\hline & 28 & 178,21 & 69.87 & 21,16 & $\mathbf{H}$ \\
\hline & 55 & 171,55 & $67=27$ & 21,74 & NI \\
\hline \multirow{3}{*}{$\begin{array}{l}\text { Secomdary } \\
\text { Fdrucation }\end{array}$} & 68 & 151,38 & 59,35 & 16,13 & NI \\
\hline & 75 & 151,44 & 59,38 & $17=18$ & INI \\
\hline & 143 & 151,41 & 59,37 & 16,63 & AI \\
\hline \multirow{3}{*}{$\begin{array}{c}\text { Higher } \\
\text { Education }\end{array}$} & 41 & 145,34 & 57.38 & 14,24 & Ax \\
\hline & 37 & 156,30 & 61,18 & 14,75 & NI \\
\hline & 78 & 150,54 & 59,18 & 15041 & $\mathrm{NI}$ \\
\hline All of them & 276 & 155,18 & 60,98 & 19,21 & NI \\
\hline
\end{tabular}

Based on Table 1, it can be understood that the public perception of early marriage in terms of education level is in the Medium category $(\mathrm{M})$. The findings can be interpreted that community support for early marriage is in the medium category, meaning that people consider early marriage is quite natural.

\section{Testing Data Analysis Requirements}

Normality tests the public perception of early marriage has Asyimp's score. Sig. 0.430 which are greater than the specified significant level of 0.05 . This means that the variable data of public perception about early marriage normal distribution. Next, test homogeneity the public perception of early marriage has Asyimp's score. Sig. ie 0,561 which are bigger than the significant level that has been set 0,05 . That is, the variable data of public perception about early marriage in terms of education level has the same or homogeneous variance.

\section{Hyphotesis Testing}

Tabel 2. Summary of Anava

\begin{tabular}{|c|c|c|c|c|c|}
\hline Varians & RJK & F $_{\text {histag }}$ & Dk & Sig. & Meaning \\
\hline $\begin{array}{l}\text { Score of Public Perception } \\
\text { Data on Early Marriage } \\
\text { based on education level }\end{array}$ & 9005,040 & 31,056 & 2 & 0,000 & Significan \\
\hline
\end{tabular}

Based on Table 2 can be drawn the conclusion there is a significant difference of public perception about early marriage in terms of education level. This is shown by Sig. 0.000 which are smaller than 0.05 . 


\section{Perceptions of the Public about Early Marriage Viewed from the Level of Education and the Difference}

The result of data analysis is known that public perception about early marriage is viewed from the level of education as a whole that is primary, middle and high education is in the Medium category (M), meaning that society considers early marriage is normal. Primary education is at the highest percentage compared with the level of secondary and higher education; a society that considers early marriage a reasonable thing is the society of the level of basic education.

There is a significant difference of public perception about early marriage in terms of education level, namely primary education, secondary education and higher education. After further testing, there is a significant difference between primary and secondary education and higher education, whereas secondary and tertiary education is no different. When viewed from the level of education, the community level of primary education considers early marriage is a natural thing. This means that the higher the education of a person then the mindset will also change towards early marriage.

Education has a very important function of transforming human assets into human capital, improving human quality (social, spiritual, intellectual and professional). The higher a person's education the greater his desire to delay marriage (Ihromi, 2004). A person who has a high level of education will know the information on reproductive health, a good marriage age and know the impact of early marriage (Emilia \& Wahyuni, 2007). The low level of education will affect the mindset of a person and can not distinguish the right and wrong of the well (UNICEF, 2005, Agustian, 2013). The level of education and knowledge leads to early marriage. Low level of education will result in information that should be received will be disconnected (Desiyanti, 2015, Qibtiyah, 2015). The low level of parental education makes low knowledge of the impact of early marriage, both in terms of legal, psychological, and biological children; parents do not feel guilty to marry off their children at any age (Kertamuda, 2009, Dwinanda, Wijayanti, \& Werdani, 2017).

Low levels of community education lead to narrow knowledge and insight, so the consequences of reproductive health caused by early marriage are unthinkable. Society considers birth is a natural process of mediocrity (Homzah \& Sulaeman, 2007). The main cause of early marriage is low access to education, especially for girls, the economy is lacking, and poverty ( Nepal, 2012, Sabirin, 2017; Pandaleke, Raule, \& Tumurang, 2017). Knowledge is an important factor that can affect one's behavior (Khomsatun, Trisnawati, \& Pantiawati, 2012; Zakiyyah \& Kes, 2015; Dwinanda, Wijayanti, \& Werd ani, 2017). The results of research and supported the opinion of some experts assert that the level of education affects the insight, perspective or assessment of society about early marriage. The higher a person's level of education then his understanding of the negative impact of early marriage will be better and will ultimately avoid early marriage.

\section{Conclusion}

The findings obtained in this study, it can be concluded that the public perceptions of early marriage viewed from the level of primary, secondary and high education are in the medium category; there is a significant difference where the average score of primary education is higher than the level of secondary education and the level of higher education. This means that the basic education level society considers early marriage is a natural thing compared with the community level of secondary education and higher education. Implementation of counseling services is expected to consider different levels of education in setting priorities for service goals 


\section{References}

Afifah, T. (2011). Perkawinan Dini dan Dampak Status Gizi pada Anak (Analisis Data Riskesdas 2010). Gizi Indonesia, 34(2).

Agustian, H. (2013). Gambaran Kehidupan Pasangan yang Menikah di Usia Muda di Kabupaten Dharmasraya. Spektrum Pls, 1(01), 205-217.

Aryanti, H. (2014). Faktor-faktor yang Berhubungan dengan Penggunaan Kontrasepsi pada Wanita Kawin Usia Dini di Kecamatan Aikmel Kabupaten Lombok Timur. Tersedia di: http://www. pps. unud. ac. id/thesis/pdf_thesi s/unud-1007-437265649-hery\% 20aryanti, 20, 1292161023.

Astuty, S. Y. (2013). Faktor-faktor Penyebab Terjadinya Perkawinan Usia Muda Dikalangan Remaja di Desa Tembung Kecamatan Percut Sei Tuan Kabupaten Deli Serdang. Welfare State, 2(1).

Azhar, S. K., \& Daharnis, I. S. (2013). Persepsi Siswa tentang Layanan Informasi Kesehatan Reproduksi Remaja yang Diberikan Guru BK SMAN 1 Kubung. Jurnal Ilmiah Konseling, 2(1), 146150.

Badan Pusat Statistik (BPS). (2016). Kemajuan yang Tertunda: Analisis data perkawinan usia anak di Indonesia, berdasarkan hasil susenas 2008-2012 dan sensus penduduk 2010. Jakarta Indonesia.

Billari, F. C., Philipov, D., \& Baizán, P. (2001). Leaving Home in Europe: The experience of cohorts born around 1960. Population, Space and Place, 7(5), 339-356.

Caldwell, B. K. (2005). Factors Affecting Female Age at Marriage in South Asia: contrasts between Sri Lanka and Bangladesh. Asian Population Studies, 1(3), 283-301.

Desiyanti, I. W. (2015). Faktor-faktor yang Berhubungan terhadap Pernikahan Dini pada Pasangan Usia Subur di Kecamatan Mapanget Kota Manado. JIKMU, 5(3), 270-280.

Djamilah, D., \& Kartikawati, R. (2016). Dampak Perkawinan Anak di Indonesia. Jurnal Studi Pemuda, $3(1), 1-16$.

Dlori. (2005). Jeratan Nikah Dini, Wabah Pergaulan. Jogjakarta: Media Abadi.

Dwinanda, A. R., Wijayanti, A. C., \& Werdani, K. E. (2017). Hubungan antara Pendidikan Ibu dan Pengetahuan Responden dengan Pernikahan Usia Dini. Jurnal Kesehatan Masyarakat Andalas, 10(1), 76-81.

Emilia, R. O., \& Wahyuni, B. (2007). Faktor-faktor yang Berhubungan dengan Pernikahan Usia Dini di Kabupaten Purworejo Jawa Tengah. Berita Kedokteran Masyarakat, 25(2), 51-52.

Fadlyana, E., \& Larasaty, S. (2016). Pernikahan Usia Dini dan Permasalahannya. Sari Pediatri, 11(2), 136-41.

Fantuzzo, J., Tighe, E., \& Childs, S. (2000). Family Involvement Questionnaire: A multivariate assessment of family participation in early childhood education. Journal of educational psychology, 92(2), 367.

Foedjiawati, F., \& Semuel, H. (2009). Pengaruh sikap, Persepsi Nilai dan Persepsi Peluang Keberhasilan terhadap Niat Menyampaikan Keluhan (Studi Kasus pada Perusahaan Asuransi AIG Lippo Surabaya). Jurnal Manajemen Pemasaran, 2(1).

Heckman, J. J. (2011). The Economics of Inequality: The Value of Early Childhood Education. American Educator, 35(1), 31.

Kertamuda, F. E. (2009). Konseling Pernikahan untuk Keluarga Indonesia. Jakarta: Salemba Humanika.

Khomsatun, Trisnawati Y., \& Pantiawati I. (2012). Hubungan Pengetahuan Remaja Putri Menikah Dini tentang Kehamilan dengan Kecemasan Menghadapi Kehamilan di Kecamatan Pulosaari Kabupaten Pemalang. Jurnal Ilmiah Kebidanan. 3(1), 37-50.

Mustika, D. (2016). Pernikahan Dini dan Hubungannya dengan Tindak Kekerasan dalam Rumah Tangga di Kota Jambi Tahun 2013-2014. Kontekstualita, 32(2). 
Nagul, W., Yusuf, A. M., \& Syahniar. (2013). Persepsi tentang Tugas dan Motivasi Kerja serta Pengaruhnya terhadap Kinerja Guru BK SMPN se-Kota Kupang. Jurnal Konseling dan Pendidikan, 1(3), 1-8.

Nepal, P. (2012). Save the Children dan World Vision International Nepal. Child Marriage in Nepal Research Report. Nepal: Horizon Creation.

Pandaleke, P., Raule, J. H., \& Tumurang, M. N. (2017). Faktor-faktor yang Berhubungan dengan Pernikahan Usia Dini di Kecamatan Ratahan Timur Kabupaten Minahasa Tenggara. Community Health, 2(1).

Qibtiyah, M. (2015). Faktor yang Mempengaruhi Perkawinan Muda Perempuan. Biometrika dan Kependudukan, 3(1). 50-58.

Rahman, U. (2017). Karakteristik Perkembangan Anak Usia Dini. Lentera Pendidikan: Jurnal Ilmu Tarbiyah dan Keguruan, 12(1), 46-57.

Sabirin, S. (2017). Perdagangan Perempuan dengan Dalih Perkawinan. Raheema, 4(1), 54-62.

Sardi, B. (2016). Faktor-faktor Pendorong Pernikahan Dini dan Dampaknya di Desa Mahak Baru Kecamatan Sungai Boh Kabupaten Malinau. eJournal Sosiatri-Sosiologi, 4(3), 194-207.

Stang, M. E. (2011). Faktor yang Berhubungan dengan Pernikahan Dini di Kelurahan Pangli Kecamatan Sesean Kabupaten Toraja Utara. J MKMI, 7(1), 105-10.

Undang-undang Perkawinan di Indonesia 1974. Surabaya: Karya Ilmu.

UNICEF. (2005). Earlv Marriage A Harmful Traditional Practice A Statistical Erplorcttion. The United Nations Chidren,s Fund (UNICEF).

Vasant, C., Ilayaraja, BS., \& Ramya, S. (2015). Assessing Parents Awareness on Health Impacts of Early Marriage: A study in selected villages of moradabad, Uttar Pradesh. International Journal of Basic Medicine and Clinical Research, 2(5), 98-102.

Yunita, A. (2014). Faktor-faktor yang Berhubungan dengan Kejadian Pernikahan Usia Muda pada Remaja Putri di Desa Pagerejo Kabupaten Wonosobo. Jurnal Ilmiah STIKES Ngudi Waluyo Ungaran, Jawa Tengah.

Zakiyyah, N. R., SKM, I. B., Kes, M., \& Kes, I. Z. M. (2015). Faktor-faktor yang Berhubungan dengan Tingkat Kepatuhan Minum Obat Penderita Kusta di Kabupaten Brebes. Unnes Journal of Public Health, 4(3). 